\title{
KADAR HB,LILA DAN BERAT BADAN IBU SAAT HAMIL BERISIKO TERHADAP KEJADIAN STUNTING PADA ANAK USIA 1-3 TAHUN
}

\author{
Ratna Dewi ${ }^{1}$, Nita Evrianasari², Ike Ate Yuviska ${ }^{3}$ \\ ${ }^{1}$ Puskesmas Kali Rejo Kabupaten Pesawaran \\ E-mail : ratnadewipesawaran@gmail.com \\ ${ }^{2}$ Dosen Program Studi DIV Kebidanan Fakultas Kedokteran Universitas Malahayati \\ E-mail : nita.nuninosa@gmail.com \\ ${ }^{3}$ Dosen Program Studi DIV Kebidanan Fakultas Kedokteran Universitas Malahayati \\ E-mail : ikeyuviska12345@gmail.com
}

\begin{abstract}
Background Children with nutritional status of stunting will experience growth disturbances until adolescence so that children's growth is lower than normal adolescents. Based on data from the Pesawaran Health Office, Kalirejo Health Center is one of the Puskemas working areas with the highest stunting incidence, as many as 203 children in 2018.

Purpose is known to the Hemoglobin, LILA, BB Maternal are at risk of the occurrence of stunting in children 1-3 years in the Kalirejo Health Center working area, Kab. . Offer of 2019.

Methods Type of quantitative research. The design of this study was an analytic survey using a cross sectional approach. The population is 900 and the sample is 90 respondents, the sampling is done by using (percentage) $10 \%$ of the total population. Analysis of data using chi square analysis.

Result Out of 60 children, 20 children (33.3\%) experienced stunting, out of 60 mothers who experienced EC, 26 mothers (43.3\%) had anemia, 34 mothers (56.7\%) did not experience any increase in weight, 27 children $(45,0 \%)$ with abnormal body length, 26 children (43.3\%) with abnormal body weight, $p$-value $<a 0,000, p$-value $<\alpha 0.008, p$-value $<\alpha 0,000, p$-value $<\alpha 0.007, p$-value $<\alpha 0.000$.

Conclusion that there is a relationship between maternal LILA riwayar during pregnancy, history of maternal HB during pregnancy, history of maternal bb during pregnancy, birth length, birth weight with stunting.

Suggestion It is expected that mothers who have children aged 1-3 years can improve the quality of children's health, beginning with the provision of adequate consumption for children, then mothers are also expected to be able to take an active role, if there is an extension related to the stunting of children.
\end{abstract}

Keywords :, Hemoglobin, Maternal BB, Birth Length, Birth Weight, Stunting

\section{ABSTRAK}

Latar Belakang Anak dengan status gizi stunting akan mengalami gangguan pertumbuhan hingga masa remaja sehingga pertumbuhan anak lebih rendah dibandingkan remaja normal. Berdasarkan data Dinkes Pesawaran, Puskesmas Kalirejo merupakan salah satu wilayah kerja Puskemas dengan kejadian stunting tertinggi, yaitu sebanyak 203 anak pada tahun 2018.

Tujuan penelitian diketahui Kadar HB, LILA, dan BB ibu saat hamil beresiko terhadap kejadian Stunting pada Anak usia 1-3 Tahun

Metode Jenis penelitian kuantitatif. Rancangan penelitian ini adalah survey analitik dengan menggunakan pendekatan cross sectional. Populasi sebanyak 900 dan sampel sebanyak 60 responden, pengambilan sampel dilakukan dengan mengunakan (persentase) $10 \%$ dari jumlah populasi. Analisa data menggunakan analisa chi square.

Hasil Dari 60 anak, 20 anak (33,3\%) mengalami stunting, dari 60 ibu yang mengalami KE, 26 ibu (43,3\%) mengalami anemia, 34 ibu $(56,7 \%)$ tidak mengalami kenaikan BB, 27 anak $(45,0 \%)$ dengan panjang badan tidak normal, 26 anak $(43,3 \%)$ dengan berat badan tidak normal, nilai $p$-value $<a 0,000, p$-value $<a 0,008, p$-value $<a$ $0.000, p$-value $<a 0.007, p$-value $<a 0.000$

Kesimpulan terdapat hubungan riwayar LILA ibu saat hamil, riwayat hb ibu saat hamil, riwayat bb ibu saat hamil, panjang badan lahir, berat badan lahir dengan kejadian stunting. 
Saran Diharapkan bagi ibu yang memiliki anak usia 1-3 tahun dapat meningkatkan mutu kesehatan anak, yang diawali dengan penyediaan konsumsi yang layak bagi anak, selanjutnya ibu juga diharapkan dapat ikut berperan aktif, jika diselenggarakan penyuluhna terkait kejadian stunting pada anak.

Kata Kunci : KEK, Hemoglobin, BB Ibu, Panjang Badan Lahir, Berat Badan Lahir, Stunting

\section{PENDAHULUAN}

Status gizi merupakan hal penting bagi perkembangan anak, dan merupakan hasil akhir dari keseimbangan antara zat gizi yang masuk kedalam tubuh anak (Endah, 2015). Status gizi adalah keadaan tubuh sebagai akibat konsumsi makanan dan penggunaan zat-zat gizi (Sulistyawati, 2012) Penilaian status gizi adalah upaya menginterpretasikan semua informasi yang diperoleh melalui penelitian antropometri, konsumsi makanan, biokimia, dan klinik (Endah, 2015).

(United Nations International Children's Emergency Fund) UNICEF pada tahun 2015 memperkirakan sekitar 870 juta orang dari 7,1 miliar penduduk dunia atau 1 dari delapan orang penduduk dunia menderita gizi buruk. Sebagian besar (sebanyak 852 juta) di antaranya tinggal di negara-negara berxkembang. Anak-anak merupakan penderita gizi buruk terbesar di seluruh dunia, dilihat dari segi wilayah, lebih dari 70 persen kasus gizi buruk pada anak didominasi oleh Negara Asia, sedangkan 26 persen di Afrika dan 4 persen di Amerika Latin serta Karibia. Setangah dari 10,9 juta kasus kematian anak didominasi kasus gizi buruk (UNICEF, 2015).

Gizi buruk dapat terjadi pada semua kelompok umur, tetapi yang perlu lebih diperhatikan pada kelompok bayi dan balita. Pada usia 0-2 tahun merupakan masa tumbuh kembang yang optimal (golden period) atau masa keemasan terutama untuk pertumbuhan janin sehingga bila terjadi gangguan pada masa ini tidak dapat dicukupi pada masa berikutnya dan akan berpengaruh negatif pada kualitas generasi penerus. Hasil Pemantauan Status Gizi (PSG) tahun 2016 mendapatkan persentase balita ditimbang $\geq 4$ kali dalam enam bulan terakhir sebesar $72,4 \%$, persentase tertinggi adalah Provinsi Jawa Tengah (90,9\%) dan terendah provinsi Papua $(50,0 \%)$ (Kementrian Kesehatan RI, 2016).

Tatalaksana penanganan masalah gizi menitikberatkan pada pencegahannya bukan lagi proses pengobatan. Orang tua berperan untuk mengontrol tumbuh kembang anaknya masingmasing dengan memperhatikan status gizinya, salah satunya dengan melakukan penimbangan berat badan, pengukuran tinggi badan serta pengukuran lingkar kepala secara teratur. Dengan penimbangan secara teratur, maslah gizi anak dapat diketahui penyimpangannya, salahsatunya dalam menentukan status gizi stunting (Prawirohartono, 2019)

Anak dengan status gizi stunting akan mengalami gangguan pertumbuhan hingga masa remaja sehingga pertumbuhan anak lebih rendah dibandingkan remaja normal. Remaja yang stunting berisiko mendapatkan penyakit kronik salah satunya adalah obesitas. Remaja stunting berisiko obesitas dua kali lebih tinggi dari pada remaja yang tinggi badannya normal (Riskesdas 2010). Oktarina (2013) mengatakan hal sama bahwa anak yang mengalami stunting pada dua tahun kehidupan pertama dan mengalami kenaikan berat badan yang cepat, berisiko tinggi terhadap penyakit kronis, seperti obesitas.Obesitas merupakan suatu kelainan atau penyakit yang ditandai oleh penimbunan jaringan lemak dalam tubuh secara berlebihan.Obesitas terjadi karena adanya ketidakseimbangan antara energi yang masuk dengan energi yang keluar.

Ada 178 juta anak didunia yang terlalu pendek berdasarkan usia dibandingkan dengan pertumbuhan standar WHO. Prevalensi anak stunting di seluruh dunia adalah $28,5 \%$ dan di seluruh negara berkembang sebesar $31,2 \%$. Prevalensi anak stunting dibenua Asia sebesar 30,6\% dan di Asia Tenggara sebesar 29,4\%. Permasalahan stunting di Indonesia menurut laporan yang dikeluarkan oleh UNICEF yaitu diperkirakan sebanyak 7,8 juta anak mengalami stunting, sehingga UNICEF memposisikan Indonesia masuk kedalam 5 besar negara dengan jumlah anak yang mengalami stunting tinggi. Data Riset Kesehatan Dasarpada tahun 2013 diketahui bahwa prevalensi kejadian stunting secara nasional adalah $37,2 \%$, dimana terdiri dari $18,0 \%$ sangat pendek dan $19,2 \%$ pendek, yang berarti telah terjadi peningkatan sebanyak $1,6 \%$ pada tahun $2010(35,6 \%)$ dan tahun 2007 (36,8 \%) (UICEF, 2013).

Gambaran kasus gizi stunting di Provinsi Lampung sejak tahun 2013 sebanyak 38.6\% kasus sangat pendek pada daerah Lampung Tengah yang merupakan kabupaten tertinggi kejadian stunting, urutan nomor dua berada pada daerah Pesawaran $33.5 \%$ dan urutan nomor tiga berada pada 
kabupaten Tulang Bawang (Profil Dinas Kesehatan Lampung, 2015).

Berdasarkan data Dinkes Pesawaran, Puskesmas Kalirejo merupakan salah satu wilayah kerja Puskemas dengan kejadian stunting tertinggi, yaitu sebanyak 203 anak pada tahun 2018. (Data Dinkes Pesawaran, 2018).

Rahmadi (2016) "Hubungan Berat Badan Dan Panjang Badan Lahir Dengan Kejadian Stunting Anak 12-59 Bulan Di Provinsi Lampung" Hasil penelitian menyimpulkan bahwa prevalensi stunting pada anak usia 12-59 bulan di Provinsi Lampung tahun 2015 adalah 26,7\%, prevalensi BBLR pada anak usia 12-59 bulan di Provinsi Lampung tahun 2015 adalah 6,5\% dan prevalensi panjang lahir rendah pada anak usia 12-59 bulan di Provinsi Lampung tahun 2015 adalah 21,8\%. Hasil analisis statistik lanjutan menyimpulkan tidak ada hubungan antara berat badan lahir dengan kejadian stunting pada anak usia 12-59 bulan di Provinsi Lampung tahun 2015 dan ada hubungan antara panjang badan lahir dengan kejadian stunting pada anak usia 12-59 bulan di Provinsi Lampung tahun 2015

Stunting merupakan indikator keberhasilan kesejahteraan, pendidikan dan pendapatan masyarakat. Dampaknya sangat luas mulai dari dimensi ekonomi, kecerdasan, kualitas, dan dimensi bangsa yang berefek pada masa depan anak. Anak usia 3 tahun yang stunting severe $(-3<z \leq 2)$ pada laki-laki memiliki kemampuan membaca lebih rendah 15 poin dan perempuan 11 poin dibanding yang stunting mild $(z>-2)$. Hal ini mengakibatkan penurunan intelegensia $(I Q)$, sehingga prestasi belajar menjadi rendah dan tidak dapat melanjutkan sekolah. Bila mencari pekerjaan, peluang gagal tes wawancara pekerjaan menjadi besar dan tidak mendapat pekerjaan yang baik, yang berakibat penghasilan rendah (economic productivity hypothesis) dan tidak dapat mencukupi kebutuhan pangan. Karena itu anak yang menderita stunting berdampak tidak hanya pada fisik yang lebih pendek saja, tetapi juga pada kecerdasan, produktivitas dan prestasinya kelak setelah dewasa, sehingga akan menjadi beban negara (Istiyanti, 2010).

Dari uraian diatas, maka peneliti tertarik melakukan penelitian dengan judul "Faktor-faktor yang berhubungan dengan kejadian stunting pada anak usia 1-3 tahun di Wilayah Kerja Puskesmas Kalirejo Kab. Pesawaran Tahun 2019"

\section{METODE PENELITIAN}

Jenis penelitian ini adalah penelitian kuantitatif. Rancangan dalam penelitian ini menggunakan desain Survei Analitik dengan pendekatan cross sectional. Populasi yang dimaksud pada penelitian ini adalah seluruh balita 1-3 tahun di Wilayah Kerja Puskesmas Kalirejo Kab. Pesawaran Tahun 2019. Dilakukan perhitungan sampel didapat sampel sejumlah 60 responden yang diambil secara random.

HASIL

Tabel 1 Distribusi Frekuensi Kejadian Stunting Pada Anak Usia 1-3 Tahun Di Wilayah Kerja Puskesmas Kalirejo Kab. Pesawaran Tahun 2019

\begin{tabular}{ccc}
\hline $\begin{array}{c}\text { Kejadaian } \\
\text { Stunting }\end{array}$ & Frekuensi & $\begin{array}{c}\text { Persentase } \\
(\%)\end{array}$ \\
\hline Stunting & 20 & 33,3 \\
Tidak Stunting & 40 & 66,7 \\
\hline \multicolumn{1}{c}{ Total } & 60 & 100 \\
\hline
\end{tabular}

Berdasarkan tabel 1 diatas maka dapat disimpulkan bahwa kejadian stunting pada anak usia 1-3 tahun di Wilayah Kerja Puskesmas Kalirejo Kab. Pesawaran Tahun 2019, dari 60 anak, 20 anak $(33,3 \%)$ mengalami stunting, dan 40 anak $(66,7 \%)$ tidak stunting.

Tabel 2 Distribusi Frekuensi Riwayat LILA Ibu Saat Hamil Yang Memiliki Anak Usia 1-3 Tahun Di Wilayah Kerja Puskesmas Kalirejo Kab. Pesawaran Tahun 2019

\begin{tabular}{lcc}
\hline \multicolumn{1}{c}{ LILA } & Frekuensi & Persentase (\%) \\
\hline KEK & 24 & 40,0 \\
Normal & 36 & 60,0 \\
\hline \multicolumn{1}{c}{ Total } & 60 & 100 \\
\hline
\end{tabular}

Berdasarkan tabel 2 diatas maka dapat disimpulkan bahwa KEK pada ibu hamil di Wilayah Kerja Puskesmas Kalirejo Kab. Pesawaran Tahun 2019, pada 60 ibu yang mengalami KEK sebanyak 24 ibu $(40,0 \%)$ dan LILA normal sebajyak 36 ibu $(60,0 \%)$

Tabel 3 Distribusi Frekuensi Riwayat $\mathrm{Hb}$ lbu Saat Hamil Yang Memiliki Anak Usia 1-3 Tahun Di Wilayah Kerja Puskesmas Kalirejo Kab. Pesawaran Tahun 2019

\begin{tabular}{ccc}
\hline Hemoglobin & Frekuensi & Persentase (\%) \\
\hline Anemia & 26 & 43,3 \\
Normal & 34 & 56,7 \\
\hline \multicolumn{1}{c}{ Total } & 60 & 100 \\
\hline
\end{tabular}


Berdasarkan tabel 3 diatas maka maka dapat disimpulkan bahwa hemoglobin pada ibu hamil di Wilayah Kerja Puskesmas Kalirejo Kab. Pesawaran Tahun 2019, pada 60 ibu yang mengalami anemia saat hamil sebanyak 26 ibu $(43,3 \%)$ dan yang memiliki hb normal sebanyak 34 ibu (56,7\%).

Berdasarkan tabel 4 diatas maka dapat disimpulkan bahwa BB ibu saat hamil di Wilayah Kerja Puskesmas Kalirejo Kab. Pesawaran Tahun 2019, pada 60 ibu sebanyak 34 ibu $(56,7 \%)$ tidak mengalami kenaikan BB, sebanyak 26 ibu $(43,3 \%)$ tidak mengalami kenaikan BB.
Tabel 4 Distribusi Frekuensi Riwayat Berat Badan Saat Hamil Yang Memiliki Anak Usia 1-3 Tahun Di Wilayah Kerja Puskesmas Kalirejo Kab. Pesawaran Tahun 2019

\begin{tabular}{ccc}
\hline BB Ibu & Frekuensi & $\begin{array}{c}\text { Persentase } \\
(\%)\end{array}$ \\
\hline BB Tidak Naik & 34 & 56,7 \\
BB Naik & 26 & 43,3 \\
\hline \multicolumn{1}{c}{ Total } & 60 & 100 \\
\hline
\end{tabular}

\section{Analisa Bivariat}

Tabel 5 Hubungan Riwayat LILA Ibu Saat Hamil Dengan Kejadian Stunting Pada Anak Usia 1-3 Tahun Di Wilayah Kerja Puskesmas Kalirejo Kab. Pesawaran Tahun 2019

\begin{tabular}{lcccccccc}
\hline & \multicolumn{9}{c}{ Stunting } & & & \\
\cline { 2 - 6 } & LILA & \multicolumn{2}{c}{ Stunting } & \multicolumn{2}{c}{ Tidak } & Total & P-Value & \multirow{2}{*}{ OR } \\
\cline { 2 - 7 } & $\mathrm{N}$ & $\%$ & $\mathrm{~N}$ & $\%$ & $\mathrm{~N}$ & $\%$ & \\
\hline KEK & 15 & 25,0 & 9 & 15,0 & 24 & 40,0 & 0,0 & 10,333 \\
Normal & 5 & 8,3 & 31 & 51,7 & 36 & 60,0 & 00 & $(2,946-36,249)$ \\
\hline Total & 20 & 33,3 & 40 & 66,7 & 60 & 100 & & \\
\hline
\end{tabular}

Berdasarkan tabel 5 diatas maka dapat disimpulkan bahwa dari 60 ibu dengan status gizi ibu saat hamil mengalami KEK sebanyak 24 orang $(40,0 \%)$ dengan kejadian stunting pada anak sebanyak 15 orang $(25,0 \%)$ tidak stunting sebanyak 9 anak $(15,0 \%)$ sedangkan pada ibu dengan riwayat status gizi saat hamil normal sebanyak 36 ibu $(60,0 \%)$, dan memiliki anak stunting sebanyak 5 anak $(8,3 \%)$ dan tidak stunting 31 anak $(51,7 \%)$.
Hasil analisa menggunakan chi-square, didapat $P$-Value $=0,000$ sehingga $P$-Value $<\alpha$ $(0,000<0,05)$ maka dapat disimpulkan terdapat hubungan riwayar LILA ibu saat hamil dengan kejadian stunting pada anak usia 1-3 tahun di Wilayah Kerja Puskesmas Kalirejo Kab. Pesawaran Tahun 2019, dengan nilai OR 10,333 yang artinya ibu dengan riwayat KEK 10 kali beresiko melahirkan anak dengan stunting, dibandingkan dengan ibu yang memiliki LILA normal

\section{Tabel 6 Hubungan Riwayat Hb lbu Saat Hamil Dengan Kejadian Stunting Pada Anak Usia 1-3 Tahun Di Wilayah Kerja Puskesmas Kalirejo Kab. Pesawaran Tahun 2019}

\begin{tabular}{|c|c|c|c|c|c|c|c|c|}
\hline \multirow{3}{*}{ Hemoglobin } & \multicolumn{4}{|c|}{ Stunting } & \multirow{2}{*}{\multicolumn{2}{|c|}{ Total }} & \multirow{3}{*}{$\begin{array}{c}P- \\
\text { Value }\end{array}$} & \multirow{3}{*}{$O R$} \\
\hline & \multicolumn{2}{|c|}{ Stunting } & \multicolumn{2}{|c|}{ Tidak Stunting } & & & & \\
\hline & $\mathrm{N}$ & $\%$ & $\mathrm{~N}$ & $\%$ & $\mathrm{~N}$ & $\%$ & & \\
\hline Tidak Normal & 14 & 23,3 & 12 & 20,0 & 26 & 43,3 & ח 008 & 5,444 \\
\hline Normal & 6 & 10,0 & 28 & 46,7 & 34 & 56,7 & 0,008 & $(1,688-17,565)$ \\
\hline Total & 20 & 33.3 & 40 & 66,7 & 100 & 100 & & \\
\hline
\end{tabular}

Berdasarkan tabel 6 diatas maka dapat disimpulkan bahwa dari 60 ibu dengan $\mathrm{Hb}$ tidak normal sebanyak 26 orang $(43,3 \%)$ dengan kejadian stunting pada anak sebanyak 14 orang $(23,3 \%)$ tidak stunting sebanyak 12 anak $(20,0 \%)$ sedangkan pada ibu dengan riwayat $\mathrm{Hb}$ normal sebanyak 34 ibu $(56,7 \%)$, dan memiliki anak stunting sebanyak 6 anak $(10,0 \%)$ dan tidak stunting 28 anak (46,7\%).

Hasil analisa menggunakan chi-square, didapat $P$-Value $=0,008$ sehingga $P$-Value $<\alpha$ $(0,008<0,05)$ maka dapat disimpulkan terdapat hubungan riwayat $\mathrm{hb}$ ibu saat hamil dengan kejadian stunting pada anak usia 1-3 tahun di 
Wilayah Kerja Puskesmas Kalirejo Kab. Pesawaran Tahun 2019. Dengan nilai OR 5,444 yang artinya ibu dengan $\mathrm{HB}$ tidak normal 5 kali beresiko melahirkan anak dengan resiko stunting dibandingkan dengan ibu yang mengalami anemia.

Tabel 7 Hubungan Riwayat BB Ibu Saat Hamil Dengan Kejadian Stunting Pada Anak Usia 1-3 Tahun Di Wilayah Kerja Puskesmas Kalirejo Kab. Pesawaran Tahun 2019

\begin{tabular}{|c|c|c|c|c|c|c|c|c|}
\hline \multirow{3}{*}{ BB } & \multicolumn{4}{|c|}{ Stunting } & \multirow{2}{*}{\multicolumn{2}{|c|}{ Total }} & \multirow{3}{*}{$\begin{array}{c}\text { P- } \\
\text { Value }\end{array}$} & \multirow{3}{*}{ OR } \\
\hline & \multicolumn{2}{|c|}{ Stunting } & \multicolumn{2}{|c|}{$\begin{array}{l}\text { Tidak } \\
\text { Stunting }\end{array}$} & & & & \\
\hline & $\mathrm{N}$ & $\%$ & $\mathrm{~N}$ & $\%$ & $\mathrm{~N}$ & $\%$ & & \\
\hline BB Naik & 17 & 28,3 & 17 & 28,3 & 34 & 56,7 & & 7,667 \\
\hline BB Tidak Naik & 3 & 5,0 & 23 & 38,3 & 26 & 43,3 & 04 & $(1,932-30,420)$ \\
\hline Total & 20 & 33,3 & 40 & 66,7 & 60 & 100 & & \\
\hline
\end{tabular}

Berdasarkan tabel 7 diatas maka dapat disimpulkan bahwa dari 60 ibu dengan BB naik sebanyak 34 orang $(56,7 \%)$ dengan kejadian stunting pada anak sebanyak 17 orang $(28,3 \%)$, tidak stunting sebanyak 17 anak $(28,3 \%)$ sedangkan pada ibu dengan riwayat BB tidak naik sebanyak 26 ibu $(43,3 \%)$, dan memiliki anak stunting sebanyak 3 anak $(5,0 \%)$ dan tidak stunting 23 anak (38,3\%).

Hasil analisa menggunakan chi-square, didapat $P$-Value $=0,004$ sehingga $P$-Value $<\alpha$ $(0.000<0,05)$ maka dapat disimpulkan terdapat hubungan riwayat $b b$ ibu saat hamil dengan kejadian stunting pada anak usia 1-3 tahun di Wilayah Kerja Puskesmas Kalirejo Kab. Pesawaran Tahun 2019, dengan nilai OR 7,667 yang artinya ibu ibu dengan BB tidak naik 7 kali beresiko melahirnak anak dengan resiko stunting, dibandingkan dengan ibu yang memiliki riwayat berat badan yang meningkat.

\section{PEMBAHASAN}

Hubungan Riwayat LILA Ibu Saat Hamil Dengan Kejadian Stunting Pada Anak Usia 1-3 Tahun Di Wilayah Kerja Puskesmas Kalirejo Kab. Pesawaran Tahun 2019

Hasil analisa menggunakan chi-square, didapat $P$-Value $=0,000$ sehingga $P$-Value $<\alpha$ $(0,000<0,05)$ maka dapat disimpulkan terdapat hubungan riwayar LILA ibu saat hamil dengan kejadian stunting pada anak usia 1-3 tahun di Wilayah Kerja Puskesmas Kalirejo Kab. Pesawaran Tahun 2019, dengan nilai OR 10,333 yang artinya ibu dengan riwayat KEK 10 kali beresiko melahirkan anak dengan stunting, dibandingkan dengan ibu yang memiliki LILA normal

Sejalan dengan teori yang dikemukakan oleh Kondisi kesehatan dan status gizi ibu selama hamil dapat mempengaruhi pertumbuhan dan perkembangan janin. lbu yang mengalami kekurangan energi kronis atau anemia selama kehamilan akan melahirkan bayi dengan berat lahir rendah (BBLR). Berat badan lahir rendah banyak dihubungkan dengan tinggi badan yang kurang atau stunting pada balita. Tinggi badan orang tua juga berkaitan dengan kejadian stunting. Ibu yang pendek memiliki kemungkinan melahirkan bayi yang pendek pula. Hasil penelitian di Egypt menunjukkan bahwa anak yang lahir dari ibu yang tinggi badan < $150 \mathrm{~cm}$ memiliki risiko lebih tinggi untuk tumbuh menjadi stunting.

Sejalan dengan penelitian yang dilakukan oleh Nurul (2016) "Hubungan Faktor Ibu Dengan Kejadian Stunting Pada Balita Di Puskesmas Piyungan Kabupaten Bantul" Pada penelitian ini terdapat hubungan antara status gizi ibu saat hamil dengan $p$-value $=0,01(<0,05)$. Hasil penelitian ini sejalan dengan penelitian yang dilakukan oleh sartono (2013) yang juga menunjukan hasil bahwa aterdapat hubungan yang signifikan antara kekurangan energi kronis pada kehamilan (KEK) dengan kejadian stunting dengan nilai $p=0,042<$ 0,05 .

Status gizi yang berlebih ataupun kurang pada ibu hamil beresiko pada kehamilan dan kesehatan anak. Kurangnya zat gizi pada ibu selama kehamilan dan pada anak di awal kehidupan akan berdampak negatif untuk jangka panjang, yaitu dapat menyebabkan kerusakan perkembangan otak, menghambat pertumbuhan fisik, serta lebih rentan untuk terkena infeksi, dan penyakit.

Penting bagi seorang wanita hamil untuk minum penambah darah minimal 90 hari kehamilan, karena bayi dalam kandungan membutuhkan zat gizi serta asam folat yang penting untuk pertumbuhan dan perkembangan janin dan mencegah cacat lahir.

Menurut peneliti status gizi ibu sangat mempengaruhi kejadian stunting hal ini 
dikarenakan, anak dalam kandungan ibu, tidak memdapatkan asupan nutrisi dari media lain, bayi hanya mendapatkan asupan makanan khusus dari ibu, sehingga jika ibu tidak mendapatkan nutrisi dengan baikm, maka pertumbuhan bayi dalam rahim akan terganggu.

Selain terganggunya pertumbuhan janin, ibu yang memiliki riwayat status gizi kurang akan beresiko melahirkan bayi secara premature, dan berat badan lahir bayi rendah, bayi yang premature belum cukup mampu untu beradaptasi dan organ yang dimilikipun belum bekerja dengan baik, hal inilah yang akan mempengaruhi tumbuh kembang anak dikemudian hari.

\section{Hubungan Riwayat $\mathrm{Hb}$ lbu Saat Hamil Dengan Kejadian Stunting Pada Anak Usia 1-3 Tahun Di Wilayah Kerja Puskesmas Kalirejo Kab. Pesawaran Tahun 2019}

Hasil analisa menggunakan chi-square, didapat $P$-Value $=0,008$ sehingga $P$-Value $<\alpha$ $(0,008<0,05)$ maka dapat disimpulkan terdapat hubungan riwayat $\mathrm{hb}$ ibu saat hamil dengan kejadian stunting pada anak usia 1-3 tahun di Wilayah Kerja Puskesmas Kalirejo Kab. Pesawaran Tahun 2019. Dengan nilai OR 5,444 yang artinya ibu dengan HB tidak normal 5 kali beresiko melahirkan anak dengan resiko stunting dibandingkan dengan ibu yang mengalami anemia.

Sealan dengan teori yang dikemukakan oleh Kemenkes R.I (2013). Ibu hamil dengan anemia sering dijumpai karena pada saat kehamilan keperluan akan zat makanan bertambah dan terjadi perubahan-perubahan dalam darah dan sumsum tulang (Wiknjosastro dkk, 2005). Nilai cut-off anemia ibu hamil adalah bila hasil pemeriksaan $\mathrm{Hb}<11,0$ $\mathrm{g} / \mathrm{dl}$. Penyebab anemia pada ibu hamil adalah karena gangguan penyerapan pada pencernaan, kurangnya asupan zat besi dan protein dari makanan, perdarahan akut maupun kronis, meningkatnya kebutuhan zat besi, kekurangan asam folat dan vitamin, menjalankan diet miskin zat besi dan pola makan yang kurang baik ataupun karena kelainan pada sumsum tulang belakang.

Hasil penelitian ini sejalan dengan penelitian yang dilakukan oleh Kristiana (2016) "Riwayat KEK dan anemia pada ibu hamil tidak berhubungan dengan kejadian stunting pada anak usia 6-23 bulan di Kecamatan Sedayu, Bantul, Yogyakarta" Hasil bivariat menunjukkan riwayat anemia saat hamil merupakan faktor risiko terjadinya stunting tetapi secara statistik tidak signifi kan $(p=0,13, O R=1,5,95 \% C l=0,85-2,73)$.

Menurut peneliti Kadar hemoglobin saat ibu hamil berhubungan dengan panjang bayi yang nantinya akan dilahirkan, semakin tinggi kadar $\mathrm{Hb}$ semakin panjang ukuran bayi yang akan dilahirkan. Prematuritas, dan BBLR juga merupakan faktor risiko kejadian stunting, sehingga secara tidak langsung anemia pada ibu hamil dapat menyebabkan kejadian stunting pada balita

\section{Hubungan Riwayat BB lbu Saat Hamil Dengan Kejadian Stunting Pada Anak Usia 1-3 Tahun Di Wilayah Kerja Puskesmas Kalirejo Kab. Pesawaran Tahun 2019}

Hasil analisa menggunakan chi-square, didapat $P$-Value $=0,004$ sehingga $P$-Value $<\alpha$ $(0.000<0,05)$ maka dapat disimpulkan terdapat hubungan riwayat $\mathrm{bb}$ ibu saat hamil dengan kejadian stunting pada anak usia 1-3 tahun di Wilayah Kerja Puskesmas Kalirejo Kab. Pesawaran Tahun 2019 , dengan nilai OR 7,667 yang artinya ibu ibu dengan BB tidak naik 7 kali beresiko melahirnak anak dengan resiko stunting, dibandingkan dengan ibu yang memiliki riwayat berat badan yang meningkat.

Sejalan dengan pendapat yang dikemukakan oleh Almatsier, Ibu hamil akan membutuhkan tambahan energi dari pada ibu yang tidak hamil, penambahan tersebut dibedakan berdasarkan umur kehamilannya yaitu: 1) Trimester I ibu hamil membutuhkan tambahan energi 150200 kal/hari; 2) Trimester II ibu hamil membutuhkan tambahan energi 250-350 kal/hari; 3) Trimester III ibu hamil membutuhkan tambahan energi 400 $\mathrm{kal} / \mathrm{hari}$ dan jumlah cairan yang dibutuhkan minimal $1500 \mathrm{ml} /$ hari (Minarti dkk, 2013).

Sejalan dengan penelitian yang dilakukan oleh Nurul (2016) "Hubungan Faktor lbu Dengan Kejadian Stunting Pada Balita Di Puskesmas Piyungan Kabupaten Bantul" Pada penelitian ini terdapat hubungan antara status gizi ibu saat hamil dengan $p$-value $=0,01(<0,05)$. Hasil penelitian ini sejalan dengan penelitian yang dilakukan oleh sartono (2013) yang juga menunjukan hasil bahwa aterdapat hubungan yang signifikan antara kekurangan energi kronis pada kehamilan (KEK) dengan kejadian stunting dengan nilai $p=0,042<$ 0,05 .

Menurut peneliti pertambahan berat badan saat hamil merupakan salah satu faktor yang mempengaruhi status kelahiran bayi (BBLR). Penambahan berat badan saat hamil perlu dikontrol karena apabila berlebih dapat menyebabkan obesitas pada bayi sebaliknya apabila kurang dapat menyebabkan bayi lahir dengan berat badan rendah, prematur yang merupakan faktor risiko kejadian stunting pada anak balita. 


\section{KESIMPULAN}

Dari hasil penelitian dengan judul "faktorfaktor yang berhubungan dengan kejadian stunting pada anak usia 1-3 tahun di Wilayah Kerja Puskesmas Kalirejo Kab. Pesawaran Tahun 2019" maka ditarik kesimpulan sebagai berikut. Hasil analisa menggunakan chi-square, didapat $P$-Value $=0,000$ sehingga $p$-value $<\alpha(0,000<0,05)$ maka dapat disimpulkan terdapat hubungan riwayar LILA ibu saat hamil dengan kejadian stunting pada anak usia 1-3 tahun di Wilayah Kerja Puskesmas Kalirejo Kab. Pesawaran Tahun 2019. Hasil analisa menggunakan chi-square, didapat $P$-Value $=0,008$ sehingga $p$-value $<\alpha(0,008<0,05)$ maka dapat disimpulkan terdapat hubungan riwayat $\mathrm{hb}$ ibu saat hamil dengan kejadian stunting pada anak usia 1-3 tahun di Wilayah Kerja Puskesmas Kalirejo Kab. Pesawaran Tahun 2019. Hasil analisa menggunakan chi-square, didapat $P$-Value $=0,004$ sehingga $p$-value $<\alpha(0.000<0,05)$ maka dapat disimpulkan terdapat hubungan riwayat bb ibu saat hamil dengan kejadian stunting pada anak usia 1-3 tahun di Wilayah Kerja Puskesmas Kalirejo Kab. Pesawaran Tahun 2019

\section{SARAN}

Bagi ibu yang memiliki anak usia 1-3 tahun diharapkan dapat meningkatkan mutu kesehatan anak, yang diawali dengan penyediaan konsumsi yang layak bagi anak, selanjutnya ibu juga diharapkan dapat ikut berperan aktif, jika diselenggarakan penyuluhna terkait kejadian stunting pada anak.

Bagi Puskesmas Kalirejo, diharapkan dapat meningkatkan keaktifan bagi petugas kesehatan untuk melakukan penyuluhan tentang status gizi anak, dan apabila menemukan anak dengan status gizi buruk, petugas kesehatan dapat langsung melakukan rujukan untuk mendapat pelayanan selanjutnya.

Puskesmas diharapkan dapat melakukan penyuluhan tentang faktor penyebab stunting, yaitu panjang badan lahir, gizi ibu saat hamil seperti memberikan penyuluhan untuk meningkatkan asupan nutrisi, mengkonsumsi tablet Fe selama 90 hari/ FE3 untuk menghindari terjadinya anemia pada ibu saat hamil. Serta lebih memperhatikan bayi BBLR maka perlu berbagai upaya untuk mengejar pertumbuhan normal (catch-up growth) Bagi Universitas Malahayati Dapat digunakan sebagai tam. ahan keperpustakan serta untuk meningkatkan pengetahuan pembaca tentang status gizi status gizi balita. Dapat menambah informasi faktor kejadian stunting dan dapat dijadikan pedoman dalam menentukan dan mengambil suatu kebijakan.

Bagi Peneliti Selanjutnya Setelah dilakukan penelitian ini, diharapkan karya tulis ilmiah ini dapat dijadikan data awal untuk penelitian selanjutnya mengenai Faktor- faktor tidak langsung yang berhubungan dengan kejadian stunting. Serta peneliti selanjtnya dapat lebih memperdalam materi dalam penyampaian kepada responden khususnya pada materi mengenai kejadian stunting.

\section{DAFTAR PUSTAKA}

Achadi LA. (2012). Seribu Hari Pertama Kehidupan Anak. Disampaikan pada Seminar Sehari dalam Rangka Hari Gizi Nasional ke 60. FKM UI, Maret 2012 Depok.

Achadi LA. (2012). Status Gizi Ibu Dan Penyakit Tidak Menular Pada Dewasa. Universitas Indonesia: Depok. http://ilkom.journal. ipb.ac.id/index. php/jgizipangan/article/viewFile/7977/6259

Anugraheni HS \& Kartasurya MI. (2012). Faktor Risiko Kejadian Stunting Pada Anak Usia 12-36 Bulan Di Kecamatan Pati, Kabupaten Pati. Program Studi IImu Gizi Fakultass Kedokteran Universitas Diponegoro. Journal of Nutrition College, Volume 1. https://ejournal3.undip.ac.id/index.php/inc/a rticle/view/725

Arifin dkk. (2013). Dalam jurnal Nadiyah; Briawan, D.; Martianto, D., 2014. Faktor risiko stunting pada anak usia 0-23 bulan di Provinsi Bali, Jawa Barat, dan Nusa Tenggara Timur (NTT). Jurnal Gizi dan Pangan, Juli 2014, 9(2): 125-132. http://journal.ipb.ac.id/index.php/jgizipanga n/article/view/8731

Arikunto, Suharsimi. (2010). Prosedur Penelitian Suatu Pendekatan Praktek. Jakarta: PT. Rineka Cipta.

Arisman,MB. (2010), Gizi Dalam kehidupan. Jakarta : EGC.

Buletin Jendela. (2018). Data Dan Informasi Kesehatan. Kesehatan RI. www. Depkes.go.id/download. php?file=download/pusdatin/buletin/Buletin -SIK..

Fatonah, (2010). Gizi dan Kesehatan Untuk Ibu Hamil. Erlangga: Jakarta.

Heni, endah. 2015. Hubungan Status Gizi Dengan Perkembangan Motorik Halus Pada Usia 35 Tahun Di Puskesmas Miri - Sragen, Skripsi. http//Journal kesehatan. Org.kes: diakses tanggal 7 Januari, 2019). 
http://digilib.

stikeskusumahusada.ac.id/files/disk1/22/01 -gdl-endahhenim-1055-1-skripsi-x.pdf

Istiany. (2014). Gizi Terapan. Remaja Rosdakarya Ofset: Bandung.

Kemenkes RI, (2010). Keputusan menteri kesehatan RI No. 1995/Menkes/SKI XII/2010 tentang Standar Antropometri Penilaian Status Gizi Anak. gizi.depkes.go.id/download/Pedoman $\% 20$ Gizi/buku-sk-antropometri-2010.pdf

Kemenkes RI. (2014). Riskesdas dalam Angka Indonesia 2013 Buku 2. Badan Penelitian dan Pengembangan Kesehatan Kemenkes RI, Jakarta.www.depkes.go.id/.../profilkesehatan-indonesia/profil-kesehatanindonesia-2014.pdf

Kementrian Kesehatan RI. (2016). Status Gizi Buruk Pada Anak.

www.depkes.go.id/.../profil-kesehatanindonesia/profil-kesehatan-indonesia2014.pdf

Margawati. (2012). "Faktor Risiko Kejadian Stunting Pada Balita Usia 24 - 36 Bulan Di Kecamatan Semarang Timur" https://ejournal3. undip.ac.id/index.php/jnc/article/view/738

Muriel., Vonaesch., Tondeur. (2017) "Factors Associated With STUNTING In Healthy Children Age 5 Years And Less Living In Banhui (RCA)". PLOS ONE. https :/ doi. org/ $10.1371 /$ journal. pone. 0182363 .

Notoatmodjo, Soekidjo. 2018. Metode Dan Riset Keperawatan.. Jakarta: Rineka Cipta.

Oktarina. (2013). Faktor Risiko Stunting Pada Balita (24-59 Bulan) Di Sumatera. Fakultas
Kesehatan Masyarakat, Universitas Indonesia, Depok. journal.ipb.ac.id > Home , Vol 8, No 3 (2013) > Oktarina

Proverawati, A. \& Ismawati, C. (2010). Berat Badan Lahir Rendah. Yogyakarta: Muha Medika.

Rochani, SKM.,MSc.,RD. dkk. (2018). Stop Stunting Dengan Konsuling Gizi. Jakarta : Penebar Plus.

Shankar., Aryastami., Kusumawardani., Besral., Jahari., Achadi (2017) "Low Birth Weight Is The Most Dominant Predictor Related To Stunting Among Children Aged 12-23 Months in Indonesia"Journal Of MBC.

Sjahmien, Moehji. (2017). Dasae-Dasar IImu Gizi. Jakarta: Pustaka Kemang.

Sukarni, Icesmi K. (2013). Kehamilan Persalinan dan Nifas. Yogyakarta: Nuha Medika.

Supariasa. (2012). Penilaian Status Gizi. Jakarta: EGC.

UNECEF. (2015). Status Gizi Anak. https://www.unicef.org/indonesia/id/A6_B_Ringkasan_Kajian_Gizi.pdf

Welina (2016) "Faktor risiko stunting pada anak umur 12-24 bulan" Hasil multivariat menunjukan bahwa faktor risiko yang berpengaruh terhadap kejadian stunting pada anak umur 1224 bulan di Kecamatan Brebes.

https://ejournal.undip.ac.id/index.php/igi/arti cle/view/8752/7081.

Prawirohartono, EP \& Hanifa, RN (2019) ; Kenali Penyebab Stunting pada Anak. https://sardjito.co.id/2019/07/22/kenalipenyebab-stunting-anak/ 